\title{
HOTEL RESOR DI PANTAI MAJU SEBAGAI WATERFRONT ARCHITECTURE DENGAN PENDEKATAN METAPHORE
}

\author{
Danang Widiatmoko ${ }^{11}$ \\ 1)Program Studi S2 Arsitektur, Fakultas Teknik, Universitas Tarumanagara, danangwidhi@gmail.com
}

Masuk: 07-01-2021, revisi: 22-02-2021, diterima untuk diterbitkan: 26-03-2021

\begin{abstract}
Abstrak
Pantai Maju adalah salah satu pulau di pantai utara Jakarta sebagai hasil dari reklamasi laut, sehingga daratan di Pantai Maju dikelilingi oleh perairan laut, yang secara arsitektur merupakan potensi alam yang menarik. Perancangan Hotel Resor di pantai Maju sangat tepat apabila menerapkan konsep waterfront, terutama pada tapak yang berada di tepi perairan. Pendekatan metafora perlu dilakukan dalam perancangan arsitekturnya, sebab dengan lokasi tapak yang berada di tepi perairan, sangat menarik apabila sosok bangunan (figure) hotel resor tersebut mempunyai identitas bentuk yang kuat. Metode perancangan yang digunakan adalah; a) Segmen Kawasan Pantai Indah Kapuk; b) Diagram Isu Kawasan dan Konsep Penyelesaian Isu; c) Analisis Konsep Perancangan; d) Analisis Pemilihan Tapak dan Tapak Terpilih; e) Analisis Tapak; f) Konsep Massa Bangunan; g) Konsep Metafora; h) Zoning dan Program Ruang; i) Façade, Eksterior dan Interior. Kesimpulan dari perancangan adalah Hotel resort di Pantai Maju yang menerapkan konsep waterfront architecture, dan architecture metaphore.
\end{abstract}

\section{Kata kunci: hotel; metaphore; reclamation; resort; waterfront}

\begin{abstract}
Pantai Maju is one of the islands on the north coast of Jakarta as a result of sea reclamation, so that the land in Pantai Maju is surrounded by marine waters, which architecturally represent an interesting natural potential. Designing a resort hotel on Pantai Maju will be interesting by applying waterfront architecture concept, especially on sites that are on the water side or sea side. A metaphorical approach needs to be done in architectural design, because with the location on the waterfront, it is very interesting if the figure of the resort hotel building has a strong form identity. The design method used is a series of design stages, starting from site potential analysis; analysis of design concepts; space program analysis; circulation analysis; analysis of the building mass. The conclusion of the design is a resort hotel in Pantai Maju which applies the concept of waterfront architecture and architecture metaphore.
\end{abstract}

Keywords: hotel; metaphore; reclamation; resort; waterfront

\section{PENDAHULUAN}

\section{Latar Belakang}

Hotel resort sebagai sarana akomodasi pada umumnya terletak di kawasan tujuan wisata. Sarana akomodasi tersebut dibutuhkan sebab jumlah pengunjung yang datang sudah memungkinkan, atau menciptakan kebutuhan akan sarana akomodasi atau tempat menginap. Dari sisi bisnis, keberadaan hotel di kawasan Pantai Maju sudah diperlukan mengingat jumlah pengunjung di kawasan tersebut terus bertambah banyak, seiring dengan semakin bertambahnya fasilitas di kawasan tersebut, yaitu semakin banyak ruko beroperasi, semakin banyak tempat-tempat berjualan di kawasan food street. Jembatan yang menghubungkan pantai Maju dengan, pulau C dan PIK 2 juga sudah beroperasi, begitu juga dengan jalan-jalan di kawan Pantai Maju, Riverwalk, dan PIK 2 juga sudah beroperasi. Semakin banyak orang dari kawasan sekitar, atau bahkan dari daerah yang yang cukup jauh seperti Bogor dan Tangerang 
yang sengaja datang ke pantai Maju untuk bersepeda dan menikmati sunset, dan menikmati beragam kuliner, atau yang bertujuan berolahraga, seperti bersepeda.

Potensi alam terbesar atau yang dominan di kawasan tersebut adalah muka air, baik berupa laut lepas maupun kanal-kanal yang terbentuk dari hasil reklamasi pantai. Untuk itu konsep arsitektur yang menghargai potensi air (water front) sangat tepat untuk diterapkan dalam perancangan hotel resort di kawasan tersebut. Potensi alam lainnya adalah adanya hutan mangrove di sepanjang pantai.

\section{Rumusan Permasalahan}

Permasalahan-permasalahan yang dilihat untuk dibahas dalam penulisan ini dirumuskan;

a. Bagaimana melakukan perancangan hotel resort di kawasan Pantai Maju yang sesuai dengan karakter sekitarnya yang berupa kawasan tepi laut dan merupakan kawasan yang bersifat water front atau tepi air.

b. Bagaimana menerapkan konsep hotel resort yang tepat untuk kawasan dengan karakterisitik seperti tersebut, dimana beragam fungsi komersial saling bertemu.

c. Bagaimana mewujudkan sosok bangunan hotel yang mempunyai karakter bentuk yang kuat (iconic), yang bersumber dari kearifan setempat.

Pokok-pokok permasalahannya adalah sebagai berikut;

Permasalahan yang ditemukan dalam penulisan ini adalah;

a. Lokasi tapak hotel berada di tepi air, tetapi dibatasi oleh jalan pedestrian public yang cukup lebar, yang bukan merupakan area hotel.

b. Luas lahan terbatas dengan KDB yang sudah maksimal, sehingga fasilitas di lantai dasar sangat terbatas ruangnya.

c. Lokasi tapak yang seolah-olah mempunyai dua muka, di mana sisi depan adalah jalan umum kawasan Pantai Maju, dan sisi belakang adalah jalur pedestrian public sepanjang tepi pulau (Jalasena), sehingga zone privat lebih sedikit areanya.

d. Aktivitas sekitar lokasi hotel yang penuh dengan kegiatan night life dan kuliner pada khususnya.

\section{Tujuan}

Tujuan dari penulisan ini adalah sebagai berikut;

a. Menghasilkan perancangan hotel resort yang baik dan disukai oleh setiap tamu yang berkunjung di kawasan pantai Maju.

b. Mendukung semakin berkembangnya kawasan pantai Maju.

c. Mengangkat nilai-nilai lingkungan dan alam ke dalam karya arsitektur hotel resort dengan suatu bentuk yang berkarakter.

\section{Manfaat}

Manfaat dari proyek hotel resort di Pantai Maju ini adalah sebagai berikut;

a. Untuk menyediakan sarana akomodasi dan tempat menginap bagi pengunjung pantai Maju yang secara khusus ingin menikmati suasana resort di kawasan tersebut.

b. Hotel resort tersebut dapat menjadi salah satu destinasi bagi orang yang datang ke pantai Maju, di mana bangunan hotel diharapkan dapat menjadi salah penanda kawasan.

c. Mendatangkan investor atau penanam modal untuk berinvestasi di kawasan pantai Maju, Riverwalk, dan PIK 2, sehingga pembangunan dan pertumbuhan ekonomi di kawasan tersebut dapat menjadi lebih cepat dan lebih baik. 


\section{KAJIAN LITERATUR}

Definisi Resort

Definisi Resort (bahasa Inggris) atau resor atau sanggaraloka adalah suatu tempat yang dapat menjadi ruang relaksasi dan rekreasi pada saat orang berkunjung untuk berlibur di tempat tersebut. Definisi lain mengenai resort adalah suatu tempat menginap yang memiliki fasilitas khusus untuk bersantai dan berolahraga, seperti misalnya olahraga tenis, golf, tracking dan jogging, juga spa (Pendit, 1999). Ada pendapat lain yang mengatakan bahwa resor adalah suatu tempat yang sering dikunjungi oleh orang untuk menikmati keindahan alamnya. (Hornby, 1974). Menurut Direktorat Jendral Pariwisata (1988:13), dinyatakan bahwa resor adalah suatu perubahan tempat tinggal untuk seseorang, di luar tempat tinggalnya, dengan tujuan untuk mendapatkan kesegaran jiwa dan raga, serta hasrat untuk mengetahui sesuatu.

Berdasar pada beberapa definisi di atas, dapat disimpulkan bahwa resort atau resor adalah sebuah tempat akomodasi yang bersifat sementara waktu (temporary) dengan memanfaatkan potensi alam, kebudayaan, dan fisik bangunan yang menjadi ciri khas setempat. Sehingga, pada umumnya yang menjadi komoditi hotel resort dapat dikelompokkan menjadi hal berikut:

a. Scene (potensi alam)

Adalah merupakan potensi fisik natural di kawasan resort, seperti kondisi alam yang berupa perbukitan, pegunungan, dataran tinggi, sungai, pantai dan laut, flora dan fauna, rekreasi dan olah raga. Scene atau potensi alamiah ini dapat dimanfaatkan untuk menciptakan suasana yang baru, yang berbeda dengan suasana perkotaan atau urban.

b. Culture (kebudayaan)

Adalah merupakan kegiatan dan kebiasaan yang menjadi ciri khas daerah setempat, seperti kehidupan sehari-hari yang bersifat tradisional, kegiatan agraris, adat istiadat, dan lain sebagainya, yang dapat mendukung terciptanya kekhasan atau keunikan bangunan dan tapak hotel resor tersebut. (Sumarno, 1999, hal. 20).

\section{Karakteristik}

Karakterisitk hotel resort menurut Kurniasih (2009), dapat memiliki 4 (empat) karakteristik yaitu berdasarkan pada;

a. Lokasi

Pada umumnya, hotel resor berlokasi di tempat-tempat yang mempunyai pemandangan indah seperti pegunungan, tepi pantai, danau, tempat wisata, dan lain sebagainya, yang jauh dari keramaian perkotaan, lalu lintas yang padat dan kebisingan. Pada hotel resort, kedekatan dengan atraksi wisata utama dan tersedianya kegiatan rekreasi merupakan tuntutan utama pasar dan turut berpengaruh terhadap harga sewa kamarnya.

b. Fasilitas Hotel

Sebagai respon terhadap keinginan pengunjung untuk berelaksasi dan bersenang-senang selama menginap, perlu disediakan fasilitas utama serta fasilitas rekreatif indoor maupun outdoor. Fasilitas utama hotel adalah kamar tidur dengan berbagai type, yang menjadi area privat. Fasilitas indoor pendukung seperti ballroom, all day dinning, gym dan spa. Sedangkan fasilitas rekreasi outdoor meliputi kolam renang, lapangan tenis, jogging track, dan pertamanan (landscape).

c. Segmen Pasar atau Target Pasar

Seperti definisi yang telah disebutkan sebelumnya, hotel resort adalah bangunan yang menyediakan akomodasi dan fasilitasnya, yang terletak di daerah wisata. Sasaran tamu hotel adalah wisatawan yang datang dengan tujuan untuk berlibur, bersenang-senang mengisi waktu libur, dan melupakan rutinitas kerja sehari-hari yang membosankan. Kebutuhan tamu untuk menginap dan bersenang-senang harus disediakan dalam bentuk fasilitas hotel. 
d. Suasana Lingkungan Taman dan Bangunan

Tamu hotel resort cenderung mencari suasana baru berupa lingkungan taman (landscape) dan keunikan bangunan hotel (architecture). Suasana baru dan ruang baru tersebut dapat menghadirkan pencerahan bagi tamu hotel.

\section{Prinsip Desain Hotel Resort}

Penekanan dalam perencanaan dan perancangan hotel yang diklasifikasikan sebagai resort dengan tujuan pleasure dan rekreasi adalah adanya kesatuan antara bangunan (architecture) dan lingkunagannya (landscape), sehingga tercipta keselarasan yang harmonis. (Triska, 2015). Jadi perancangan outdoor dan indoor dari bangunan hotel resor, merupakan kesatuan ruang yang saling melengkapi. Prinsip yang lainnya adalah keunikan dan kekhasan wujud bangunan hotel yang berdasar pada local wisdom.

\section{Klasifikasi Hotel Resort Berdasarkan Lokasinya}

Klasifikasi resort dikelompokkan berdasarkan letak orientasi view dan lokasinya, serta kelengkapan fasilitas dan atraksi wisatanya (Marlina, 2008). Pengelompokkan berdasar lokasinya adalah sebagai berikut;

\section{Mountain Resort Hotel}

Mountain resort hotel (hotel resor di pegununangan) terletak di daerah pegunungan yang menawarkan pemandangan indah serta budaya lokal di lingkungan sekitar. Fasilitas yang disediakan lebih ditekankan pada hal-hal yang berkaitan dengan hiburan alam dan rekreasi yang bersifat alami dancultural, seperti mendaki gunung, hiking, panjat tebing, dan lain sebagainya.

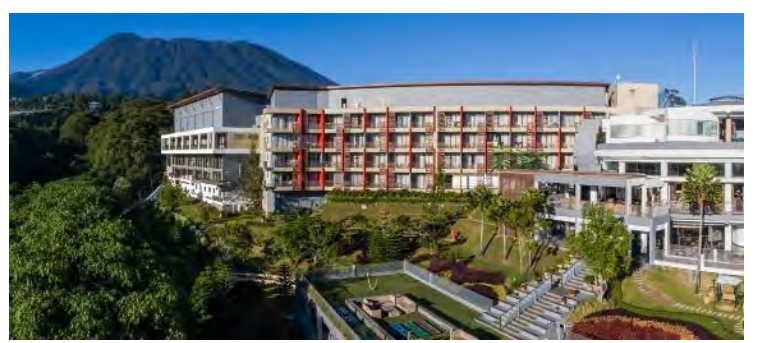

Gambar 1. Pesona Alam Resort

Sumber: https://www.bogorraincake.com/2017/11/27/5-penginapan-di-bogor-suguhkanpemandangan-indah

\section{Beach Resort Hotel}

Adalah hotel resor yang mengutamakan pada potensi alam berupa pantai dan laut sebagai daya tarik bagi pengunjung. Fasilitas rekreasi dan olahraga air merupakan atraksi utama sebagai daya tarik bagi pengunjung.

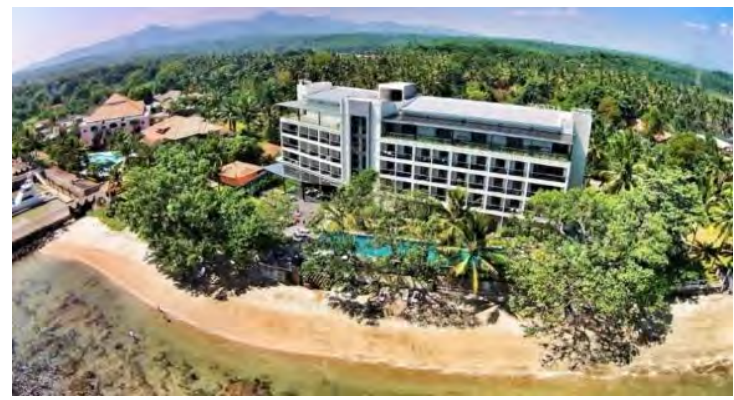

Gambar 2. Hotel Anyer Beach Resort

Sumber: https://www.sembo.co.uk/d/hotel-258258_aston_anyer_beach_resort_java_jakarta 


\section{Lake Resort Hotel}

Adalah hotel resort yang berada di tepi danau, yang memanfaatkan danau sebagai view dan atraksi utama.

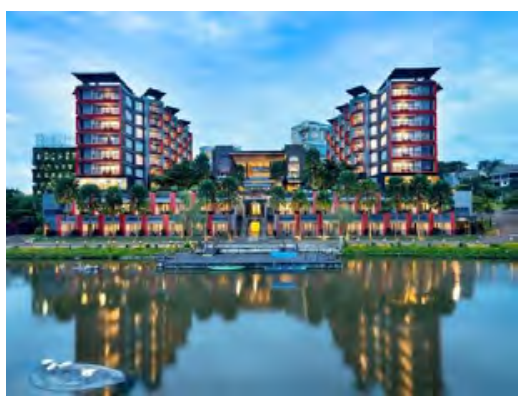

Gambar 3. Hotel Aston Sentul Lake Resort

Sumber:https://www.agoda.com/aston-sentul-lake-resort-conference-center

\section{Village Resort Hotel}

Village resort hotel atau hotel resor pedesaan umumnya berada di dalam pemukiman atau perkampungan yang unik dan tradisional. Menyelami kebudayaan masyarakat sekitar, bergabung dengan berbagai kegiatan masyarakat, meninggalkan gaya hidup modern dan larut dalam kehidupan masyarakat pedesaan merupakan kegiatan utama yang dijadikan focus utama.

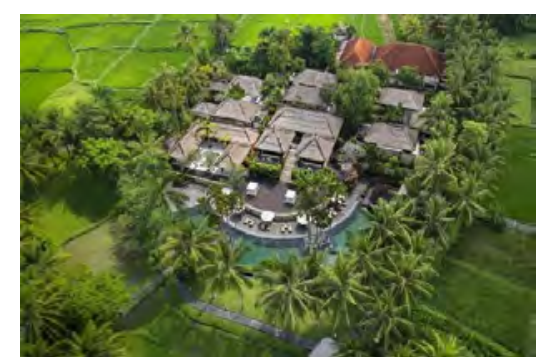

Gambar 4. Ubud Village Resort

Sumber: https://www.booking.com/hotel/id/the-ubud-village-resort.html

\section{Forest Resort Hotel}

Pada umunya, hotel resor ini terletak di daerah hutan yang berkarakter khas dengan berbagai macam jenis flora dan fauna. Wisatawan dapat menikmati pemandangan alam serta mempelajari segala yang ada di dalam hutan. Kebanyakan hotel resor type ini banyak digunakan untuk penelitian dan pendidikan tentang konservasi hutan lindung yang ada. Pada bebrapa resor mahal, suasana hutan yang masih asli dan jauh dari kemodern-an justru menjadi nilai mahal yang dicari oleh kalangan tertentu.

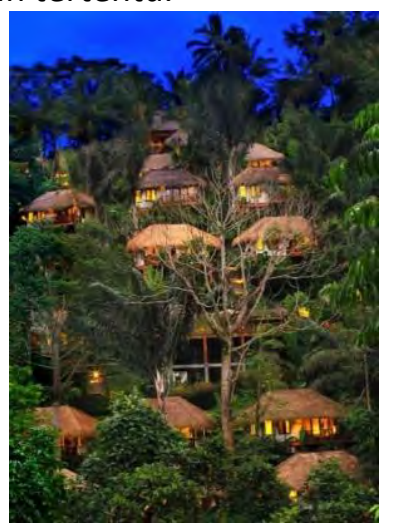

Gambar 5. Hotel Nandini Bali

Sumber: https://gogoo-tour.com/blog/Shangri-la-hidden-in-the-jungle-of-Bali-\%E2\%80\%93-A-retreataway-from-the-world 


\section{Marina Resort Hotel}

Hotel resor tipe ini pada umumnya berada di daerah pelabuhan, atau dekat dengan saran transportasi dan wahana air. Sebagai penunjang fasilitasnya, hotel ini memanfaatkan potensi utama daerah tersebut dengan melengkapi fasilitas dermaga dan kegiatan yang berhubungan dengan air.

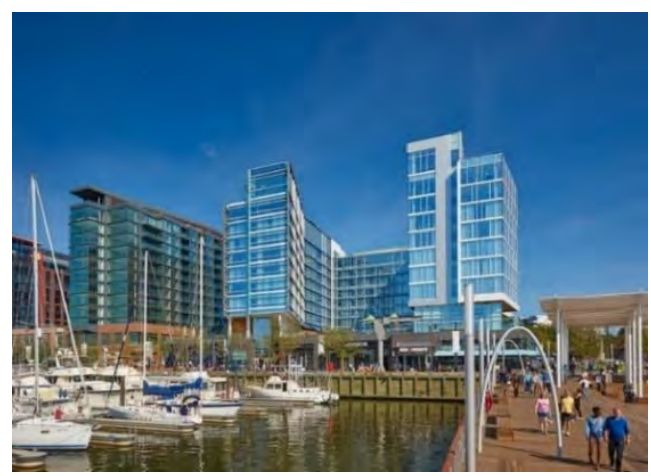

Gambar 6. Hotel The Wharf, Washinton DC

Sumber: https://www.metropolismag.com/cities/washington-dc-waterfront-smithgroupjjr/

\section{Konsep Waterfront}

Pengertian waterfront dalam Kamus Bahasa Indonesia secara harafiah dapat diartikan sebagai daerah tepi laut, bagian kota yang berbatasan dengan air, daerah pelabuhan (Echols, 2003). Waterfront Development juga dapat diartikan suatu proses dari hasil pembangunan yang memiliki kontak visual dan fisik dengan air dan bagian dari upaya pengembangan wilayah perkotaan yang secara fisik alamnya berada dekat dengan air dimana bentuk pengembangan pembangunan wajah kota yang terjadi berorientasi ke arah perairan.

Berdasarkan tipe proyek, waterfront dapat dibedakan menjadi 3 jenis, yaitu:

a. Konservasi adalah penataan waterfront kuno atau lama yang masih ada sampai saat ini dan menjaganya agar tetap dinikmati masyarakat. Contohnya adalah hotel Fullerton, di tepi sungai Singapura, yang selesai dibangun pada tahun 1928.

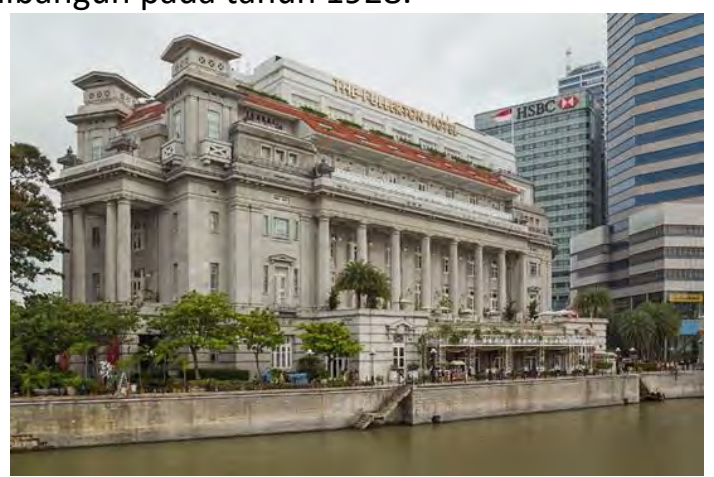

Gambar 7. Hotel Fullerton Singapore

Sumber: https://en.wikipedia.org/wiki/The_Fullerton_Hotel_Singapore

b. Redevelopment atau pembangunan kembali adalah upaya menghidupkan kembali fungsifungsi waterfront lama yang sampai saat ini masih digunakan untuk kepentingan masyarakat dengan mengubah atau membangun kembali fasilitas- fasilitas yang ada. 


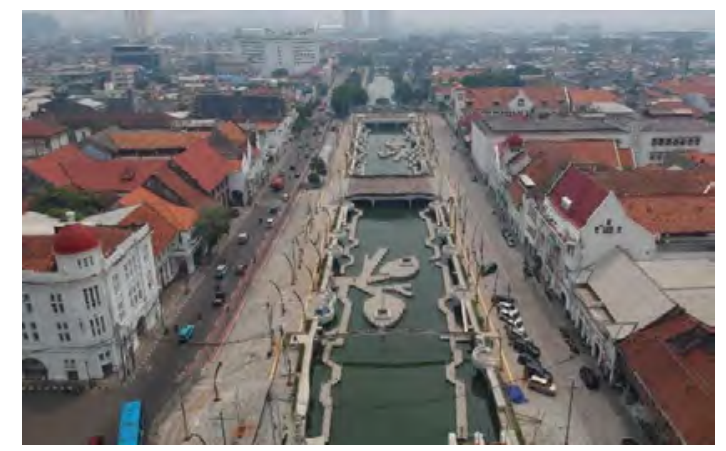

Gambar 8. Kali Besar kota Tua jakarta

Sumber: https://www.liputan6.com/ramadan/read/3987231/cantiknya-kali-besar-kota-tua-yang-miripsungai-cheonggyecheon-di-seoul

c. Development atau pengembangan adalah usaha menciptakan waterfront yang memenuhi kebutuhan kota saat ini dan masa depan dengan cara mereklamasi pantai.

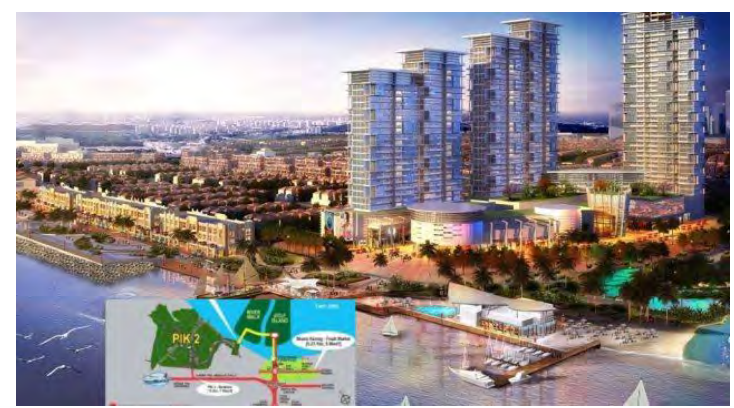

Gambar 9. Hotel di kawasan PIK 2

Sumber: https://transaksiproperty.com/2017/10/02/singapura-masuk-pantai-indah-kapuk-untuk-garapproperti-waterfront

\section{Berdasarkan Program Ruang}

adapun berdasarkan fungsi dan program ruangnya, waterfront development dapat dibedakan menjadi 4 type proyek, yaitu:

a. Mixed-used waterfront

Adalah type pembangunan tepi air yang merupakan kombinasi dari perumahan, sarana akomodasi, perkantoran, restoran, pasar, rumah sakit, dan/atau tempat-tempat kebudayaan.

b. Recreational waterfront

Adalah semua kawasan waterfront yang menyediakan sarana-sarana dan prasarana untuk kegiatan rekreasi, seperti pertamanan, arena bermain, tempat pemancingan, dan fasilitas untuk kapal pesiar.

c. Residential waterfront

Adalah perumahan, apartemen, dan resort yang dibangun di pinggir perairan, misalnya perumahan di tepi danau, kanal, dan tepi pantai.

d. Working waterfront

Adalah bangunan fisik yang berada di tepi air yang berfungsi sebagai ruang kerja dan berusaha, seperti misalnya bangunan penangkapan ikan komersial, reparasi kapal pesiar, industri berat, dan fungsi-fungsi pelabuhan (Breen, 1996).

\section{Pengertian Metafora}

Secara etimologis, terminologi metafora dibentuk melalui perpaduan dua kata Yunani, yaitu "meta" (diatas) dan "pherein" (mengalihkan/memindahkan). Dalam bahasa Yunani Modern, kata metafora juga bermakna "transfer" atau "transpor". Jadi dapat dikatakan bahwa metafora 
adalah pengalihan citra, makna, atau kualitas sebuah ungkapan kepada suatu ungkapan lain (Classe, 2000).

Terdapat beberapa pengertian dan definisi terhadap metafora yang disampaikan para ahli. Berikut ini adalah pengertian metafora menurut para ahli;

a. Menurut Aristoteles, metafora adalah sarana berpikir yang sangat efektif untuk memahami suatu konsep yang abstrak, yang dilakukan dengan cara memperluas makna dari konsep tersebut, dengan cara melakukan perbandingan dengan konsep lain yang sudah dipahami dan disepakati secara umum. (Orthony, 1992)

b. Metafora adalah ungkapan yang bersifat figurative, yang berdasarkan pada perbandingan hal satu dengan lainnya. (Larson, 1988).

c. Metafora merupakan sesuatu yang istimewa, dan hanya digunakan oleh orang-orang yang berbakat menggunakannya sebagai ornament retorika. (Amstrong, 1936).

\section{Pengertian Metafora Dalam Arsitektur}

Di dalam dunia arsitektur, metafora juga diterapkan sebagai metode atau cara berpikir sebagai pendekatan dalam perancangan arsitektur. Berikut ini adalah pengertian metafora menurut para ahli:

a. Geoffrey Broadbent (1995)

Metafora dalam arsitektur merupakan salah satu metode kreativitas yang ada dalam design spectrum arsitek atau perancang.

b. Anthony C Antoniades (1990)

Metafora dalam arsitektur adalah suatu cara memahami suatu hal, dengan menerangkan suatu objek dengan objek lain, serta mencoba untuk melihat suatu objek sebagai sesuatu yang lain.

c. C Snyder dan Anthony J Catennese (1989)

Metafora mengindentifikasi pola-pola yang mungkin terjadi dari hubungan-hubungan pararel dengan melihat keabstrakannya.

\section{Jenis-Jenis Metafora}

Metafora merupakan sebuah pendekatan dalam arsitektur yang memiliki konsep sebagai idenya dan hasilnya adalah berupa makna yang terungkap secara konkrit maupun abstrak dari perancang kepada pengguna atau pelaku bangunan sehingga bermakna konotatif di samping sebagai fungsi utamanya sebagai bangunan.

Menurut Anthony C Antoniades (1990) dalam bukunya Poetic of Architecture, terdapat tiga jenis kategori dari pendekatan metafora dalam arsitektur. Ketiga jenis itu adalah:

a. Metafora Konkrit/Nyata (Tangible)

Metafora yang berasal dari hal-hal visual serta spesifikasi/karakter tertentu dari sebuah benda seperti sebuah rumah adalah puri atau istana, maka wujud rumah menyerupai istana.

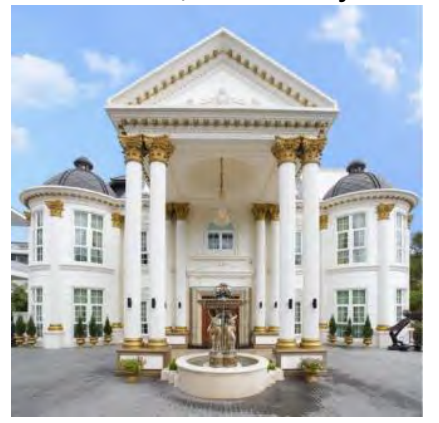

Gambar 10. Rumah yang seperti istana

Sumber: https://insinyurbangunan.com/wp-content/uploads/2018/10/rumah-mewah-syahrini.jpg 
b. Metafora Abstrak (Intangible)

Metafora yang berasal dari sebuah konsep, hakikat manusia, nilai-nilai dan ide seperti: individualisme, naturalisme, komunikasi, tradisi dan budaya. Ide dari metafora jenis ini berasal dari sebuah konsep yang abstrak.

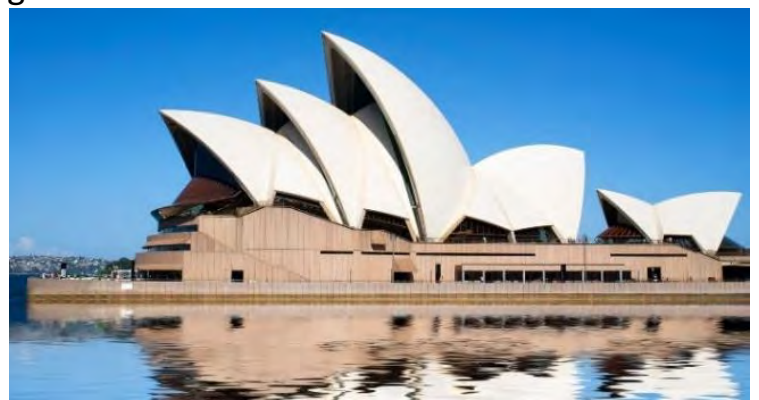

Gambar 11. Sydney Opera House

Sumber: https://architecture.knoji.com, 2017

c. Metafora Kombinasi Abstrak-Nyata

Merupakan penggabungan antara metafora konkrit dan metafora abstrak dengan membandingkan suatu objek visual dengan yang lain dimana mempunyai persamaan nilai konsep dengan objek visualnya. Metafora kombinasi dapat dipakai sebagai sarana dan acuan kreativitas perancangan.

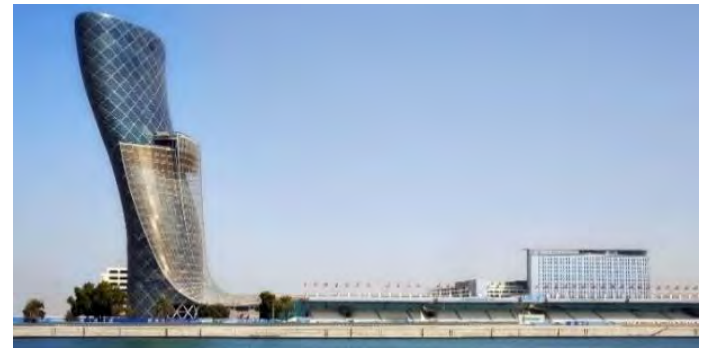

Gambar 12. Capital Gate, Abu Dhabi

Sumber: https://archello.com/project/the-capital-gate-adnec

\section{KONSEP PERANCANGAN}

Konsep desain atau perancangan yang digunakan untuk merancang proyek adalah pendekatan arsitektur kontemporer. Arsitektur kontemporer mempunyai sifat untuk selalu menuntut terjadinya perubahan seiring perkembangan zaman yang diikutinya (Schirmbeck, 1988). Dalam perancangan proyek ini, arsitektur kontemporer dibentuk dari beberapa pendekatan desain, yaitu:

a. Concept of form and function runs together, yaitu desain yang bekerja secara bolak-balik antara fungsi dan bentuk; dapat dimulai dari analisis program, dan dapat dimulai dari tipologi bentuk berdasarkan konsep desain bentuk (masa). Namun keduanya masih memiliki hubungan yang kuat dan ada timbal balik, meskipun dapat berjalan sendiri-sendiri, serta tetap menjadi satu-kesatuan dalam proyek arsitektur (Trisno \& Lianto, 2019).

b. Sustainable architecture, yaitu merancang dengan pendekatan penerapan sistem dan konsep "green", salah satunya dalam perancangan proyek, memperbanyak vegetasi yang bertujuan memberi kontribusi untuk paru-paru kawasan, serta penggunaan material yang ramah lingkungan dan ringan akan pengudaraan dan pencahayaan alami. Salah satu komponen terpenting bangunan adalah fasadnya yang harus didesain dengan baik dan hatihati karena sangat mempengaruhi kesejukan udara di dalam ruang interiornya (Bauer, Mösle, \& Schwarz, 2007). Desain fasad yang baik memiliki target penerapan sistem teknologi yang minim, namun tetap memperhatikan aspek-aspek pengukuran, seperti 
pengukuran insulasi suhu dan suara (proteksi kesilauan); pencahayaan alami; pengudaraan (ventilasi) alami (Bauer, Mösle, \& Schwarz, 2007).

c. Contextualism in responding site, yaitu menggubah bentuk dan masa sesuai konteks proyek dengan lingkungan tapak maupun kawasannya, dengan cara penggambaran diagram abstrak sebuah objek kontekstual, lalu digubah kembali menjadi bentuk arsitektural, yaitu bentuk yang masih ada kesesuaian dan berhubungan dengan konsep objek kontekstual (Jormakka, 2008).

\section{METODE PERANCANGAN}

Berdasarkan kajian teori diatas, maka metode perancangan menggunakan tahapan perancangan proyek sebagai berikut:

a. Segmen Kawasan Pantai Indah Kapuk.

b. Diagram Isu Kawasan dan Konsep Penyelesaian Isu

c. Analisis Konsep Perancangan.

d. Analisis Pemilihan Tapak dan Tapak Terpilih.

e. Analisis Tapak.

f. Konsep Massa Bangunan.

g. Konsep Metafora

h. Zoning dan Program Ruang

i. Façade, Eksterior dan Interior

\section{DISKUSI DAN HASIL}

\section{Segmen Kawasan Pantai Indah Kapuk}

Kawasan Pantai Indah Kapuk (PIK) adalah sebuah kompleks perumahan yang terletak di Kelurahan Penjaringan, Jakarta Utara dan Kelurahan Kapuk, Jakarta Barat. PIK adalah salah satu kompleks perumahan paling bergengsi di Jakarta, bersama Menteng, Pondok Indah, dan Puri Indah. Walaupun sebagian besar diisi perumahan, PIK juga memiliki pertokoan di jalanjalan utama, seperti di Jl. Pantai Indah Utara, Jl. Pantai Indah Selatan, dan Jl. Marina Indah, serta The Cordoba dan Crown Golf di Jalan Marina Indah Road terkenal akan restoran dan kafenya.

Kawasan Pantai Indah Kapuk diperluas dengan pengembangan reklamasi pantai, yang saat ini terdiri dari pulau D (Pantai Maju) dan pulau C (Pantai Kita). Kemudian diperluas lagi dengan adanya kawasan PIK 2.

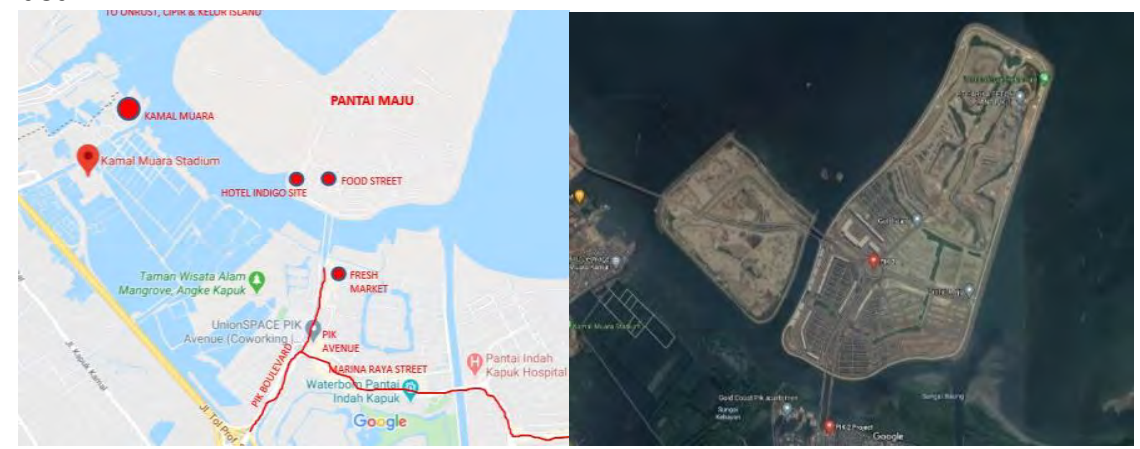

Gambar 13. Jakarta Barat, Grogol Petamburan, dan segmen kawasannya Sumber: Dokumentasi penulis (disunting dari Google), 2020

\section{Diagram Isu Kawasan dan Konsep Penyelesaian Isu}

Penelitian dan observasi kawasan Pantai Indah Kapuk dikaitkan dengan potensi tapak yang berupa lahan hasil reklamasi, yang dikelilingi oleh perairaran, baik berupa laut lepas maupun kanal-kanal pemisah daratan, yang fungsinya adalah supaya kanal tersebut tetap dapat mengalirkan air ke laut lepas. 


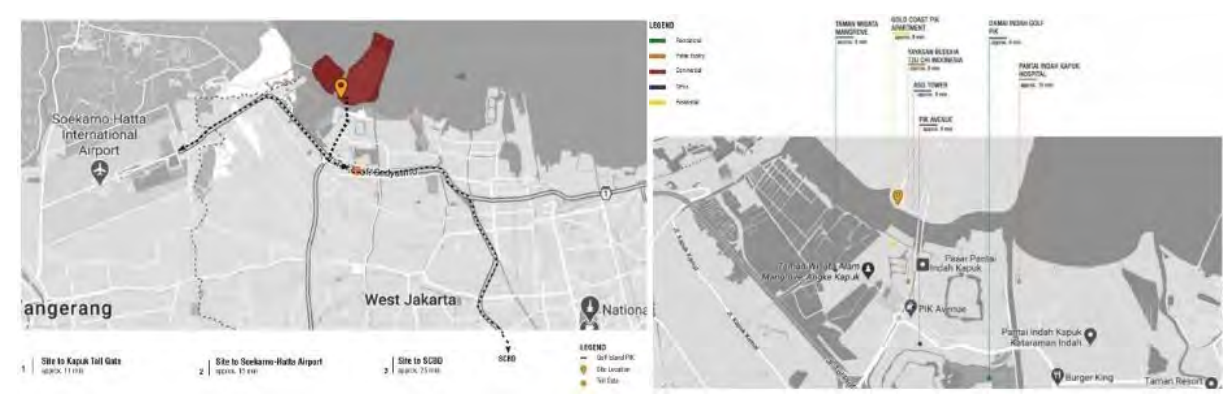

Gambar 14. Pemetaan potensi kawasan berupa kawasan tepi air (waterfront) Sumber: Penulis, 2020

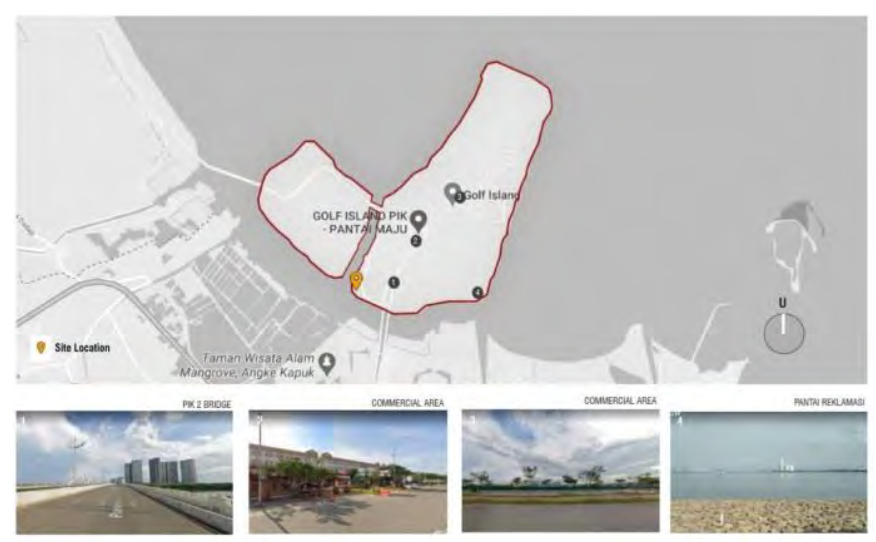

Gambar 15. Pemetaan potensi kawasan berupa kawasan tepi air (waterfront) Sumber: Dokumentasi penulis, 2020

Setelah melakukan observasi dan riset terhadap kawasan, berikut adalah diagram penjelasan isu yang diangkat dan konsep penyelesaian isu, baik isu umum maupun isu khusus:

a. Area dengan intensitas tinggi untuk fungsi komersial terdapat di sepanjang boulevard utama pantai Maju (Golf Is/and).

b. Area tepi air (waterfront) juga terjadi intensitas komersial sebagai pendukung fungsi rekreasi.

c. Area tepi air di sisi barat, cenderung lebih tinggi intensitasnya, sebab sunset merupakan daya tarik yang kuat.

d. Area yang mempunyai view sunset dan view hutan mangrove cenderung menjadi residential.
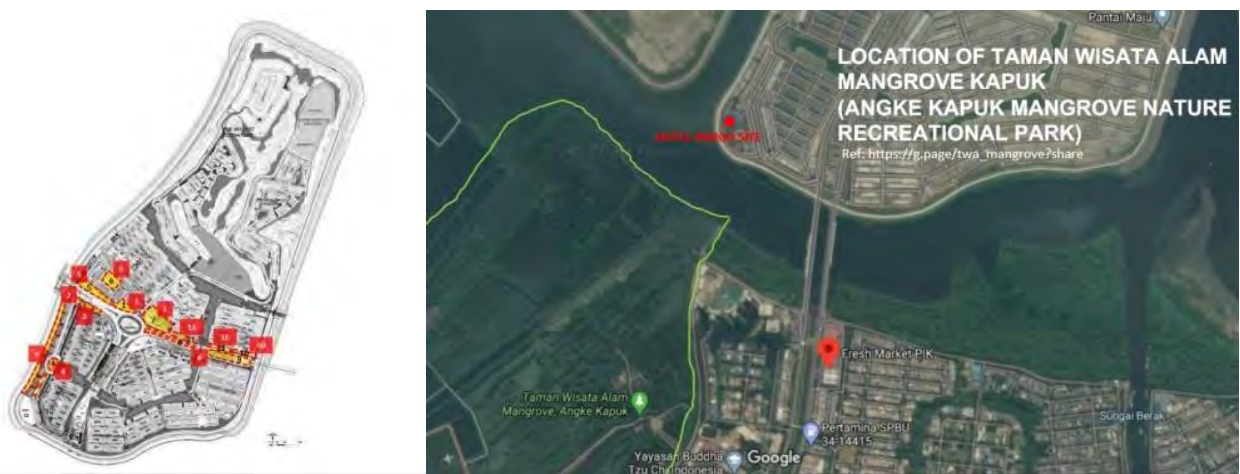

Gambar 16. Diagram isu kawasan dan konsep penyelesaian isu Sumber: Penulis, 2020

Analisis Konsep Perancangan 
Melalui analisis data lapangan, dapat dikelompokkan data perancangan yang dapat menjadi acuan konsep perancangan sebagai berikut;

Tabel 1. Analisis data lapangan

\begin{tabular}{|c|c|c|c|}
\hline No & Topik & Penjelasan & Data Gambar \\
\hline 1 & Kuliner & $\begin{array}{l}\text { Kekayaan dan keanekaragaman kuliner, } \\
\text { penekanannya pada pola kegiatan dan } \\
\text { zonasi kegiatan. Karakter kegiatan bersifat } \\
\text { leisure dan entertainment, jadi lebih } \\
\text { bersifat santai, bebas, dan hiburan. } \\
\text { Ruang-ruang publik untuk kegiatan santai } \\
\text { dan hiburan menyatu sebagai ruang } \\
\text { komersial. }\end{array}$ & \\
\hline 2 & $\begin{array}{l}\text { Potensi } \\
\text { Alam }\end{array}$ & $\begin{array}{l}\text { Potensi alam berupa pemandangan hutan } \\
\text { mangrove dan suasana tepi air (water } \\
\text { front). Penekanannya pada potensi alam, } \\
\text { dan kecenderungan kembali ke suasana } \\
\text { alam (back to nature). }\end{array}$ & \\
\hline
\end{tabular}

3 Sejarah Lokasi terdekat adalah pulau Kelor yang menjadi saksi sejarah kolonialisme di Nusantara. Penekannanya pada jejak-jejak bentukan sejarah dalam wujud arsitekturnya. Penggunaan material setempat seperti batu-bata dan batu alam juga menjadi catatan.

Fragmen sejarah di kawasan tersebut dapat menjadi nilai kearifan lokal.

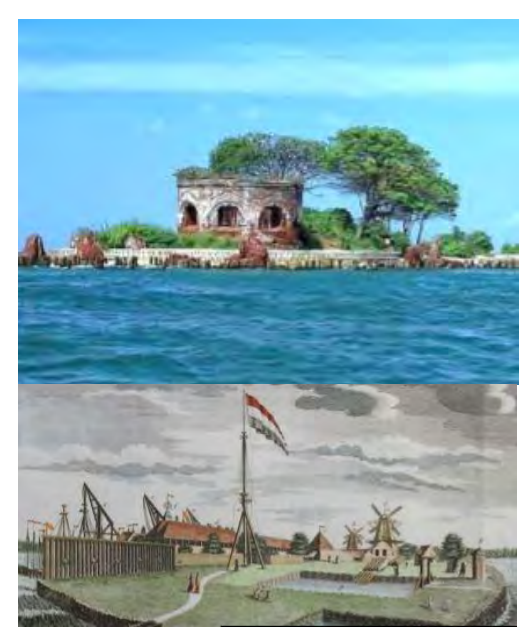

Sumber: Sumber: Penulis, 2020

\section{Analisis Pemilihan Tapak dan Tapak Terpilih}

Proses analisis pemilihan tapak: (1) Visi dan program dari developer adalah diperlukan ada hunian yang bersifat komersial, baik itu berupa hotel atau service apartment, yang lebih bersifat resort, mengingat kawasan pantai maju belum memiliki saran akomodasi komersial. (2) Berdasar visi dan program tersebut, maka lokasi yang tepat untuk program tersebut adalah yang memiliki view yang menarik, dan pada saat sunset atau matahari tenggelam menjadi tempat untuk menikmati sunset. (3) Berdasarkan hal tersebut, lokasi tapak sebaiknya berada di tepi barat pantai Maju, dan menghadap ke hutan mangrove, seperti yang tertera pada gambar iliustrasi di bawah ini, dan mempunyai sunset view yang terbaik. 


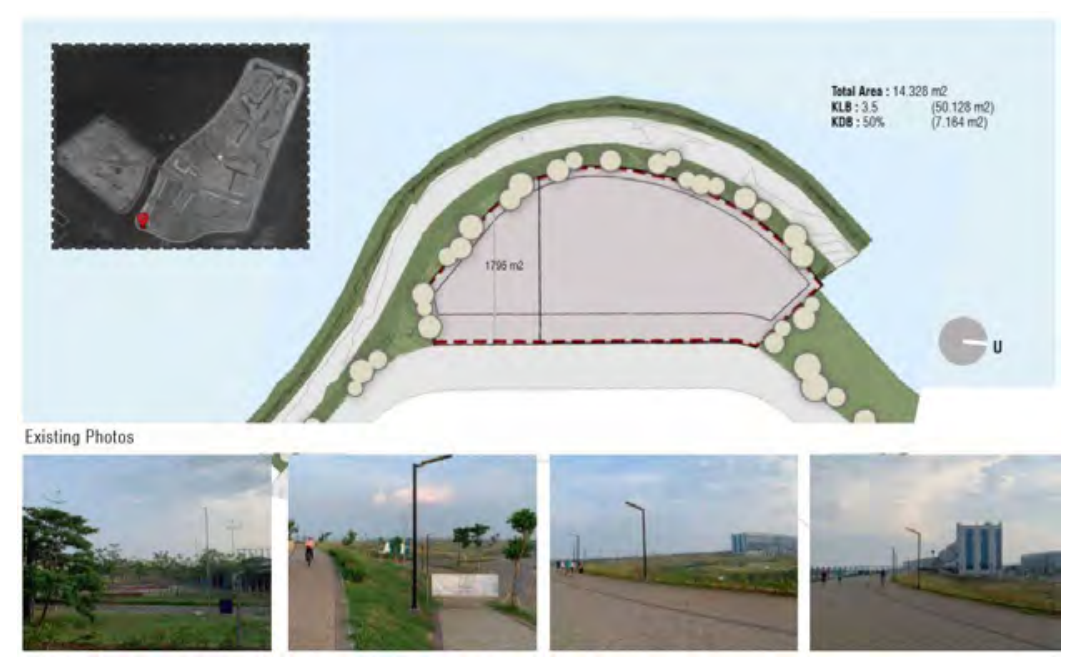

Gambar 17. Analisis pemilihan tapak Sumber: Penulis, 2020

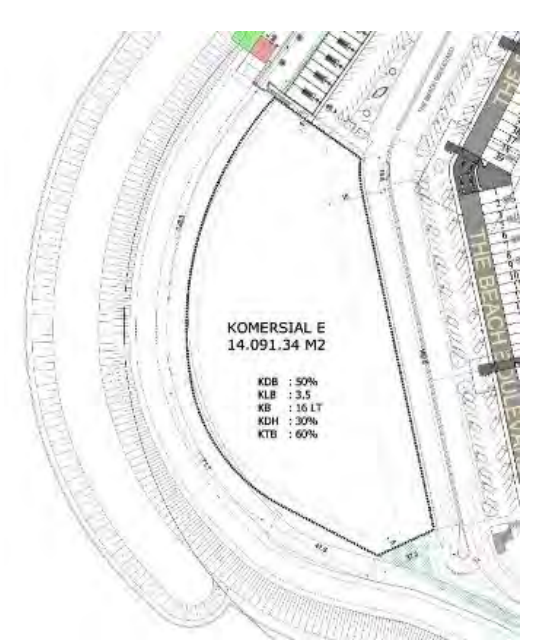

Gambar 18. Tapak terpilih dan detailnya

Sumber: Dokumentasi penulis (acuan data peraturan tapak dari Jakarta Satu), 2020

\section{Analisis Tapak}

Proses analisis tapak adalah dengan cara melakukan analisis empat aspek utama, yaitu:

- Orientasi tapak dan bangunan, tapak berorientasi ke hutan mangrove diseberang kanal, serta perairan di sekitar tapak.

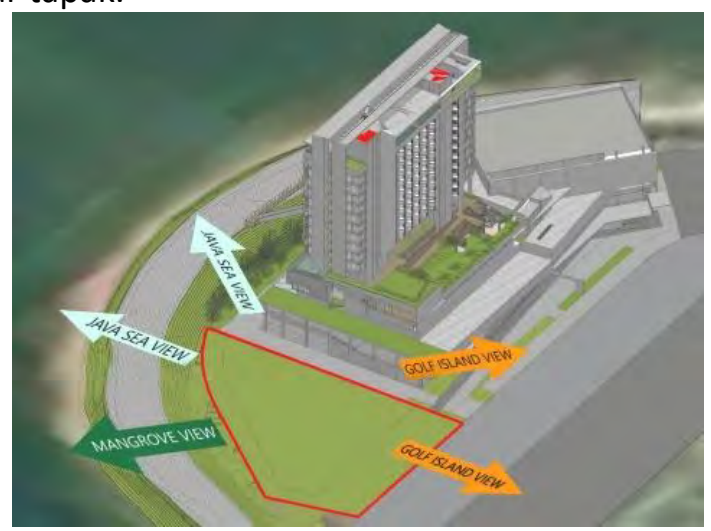

Gambar 19. Orientasi tapak terhadap lingkungannya.

Sumber: Penulis, 2020 
- Aksesibilitas, Di pantai Maju belum disediakan public transport, jadi akses menuju site dapat ditempuh dengan kendaraan pribadi seperti mobil, motor atau sepeda. Rencananya akan disediakan shuttle bus yang melayani rute di sekitar pantai Maju.

- Hierarki jalan, Di sepanjang tepian pantai Maju terdapat tanggul setinggi 3 meter yang mengelilingi daratan pantai maju. Tanggul tersebut berfungsi sebagai penahan air laut pada saat air pasang. Tanggul tersebut juga difungsikan sebagai jalur pedestrian dan jalur sepeda yang mengelilingi pantai Maju, disebut Jalasena.

- Ketinggian bangunan, Berdasar batasan regulasi, Ketinggian Bangunan maksimal adalah 16 lapis, apabila dikonversi menjadi 85 meter, tetapi berdasar KKOP tinggi maksimal 128 meter.

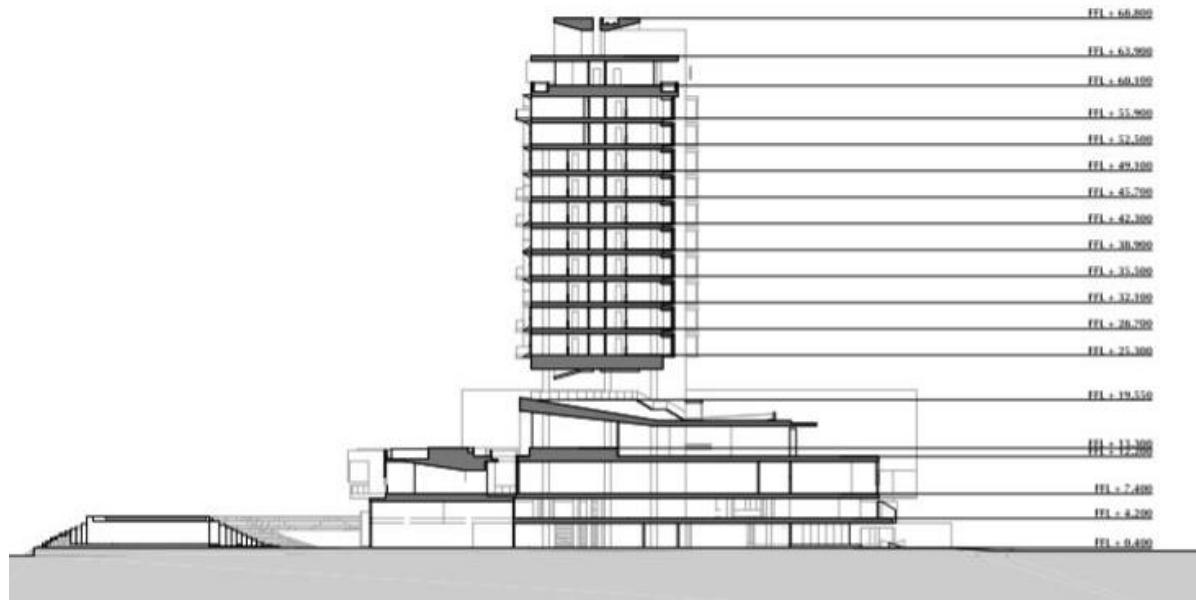

Gambar 20. Ketinggian bangunan.

Sumber: Penulis, 2020

\section{Konsep Massa Bangunan}

Konsep masa bangunan hotel resort di Pantai Maju dibentuk dari hasil keseluruhan analisis, yang telah disesuaikan dengan metode-metode desain yang diaplikasikan dalam perancangan:

- Close and open space, yaitu bangunan memiliki sifat terbuka dan tertutup sesuai karakteristik fungsional ruang hotel resort, dimana ruang yang privat lebih bersifat tertutup, sedangkan ruang yang public lebih bersifat terbuka.

- Transparan dan masif, yaitu dengan penggunaan material yang transparan pada fasad, seperti penggunaan kaca, dan secondary skin, dipadukan dengan konsep close dan open space, tetapi masa bangunan tetap bersifat masif agar sosok bangunannya tetap merupakan suatu figure yang menonjol.

- Elemen tribun dan tangga, yaitu pengaplikasian tribun pada open space bangunan sebagai area outdoor program bangunan dan area santai. Tribun-tribun ini dilengkapi tangga pengunjung sebagai akses dari satu lantai ke lantai lainnya, yang disusun secara cascade atau berundak-undak.
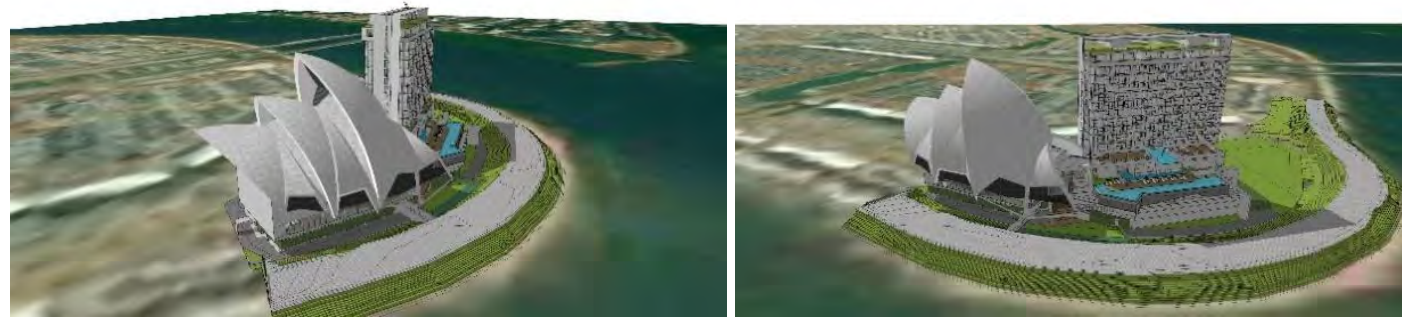

Gambar 21. Konsep massa bangunan

Sumber: Penulis, 2020

Konsep Metafora 
Konsep arsitektur Metafora pada hotel Resort di Pantai Maju menggambarkan suatu obyek yang mempunyai relevansi dengan lokasinya di tepi perairan pantai, yang umumnya dipilih adalah bentuk layar perahu, bentuk cangkang, ataupun bentuk kura-kura atau hewan laut lainnya yang bercangkang. Metafora bentuk tersebut dapat menjadi multi tafsir sehingga pengamat bangunan dapat menafsirkannya secara beragam maknanya. Dalam hal ini, wujud atau figure yang mewakili dapat berbentuk seperti layar atau cangkang (shell). Bentuk seperti mercusuar (light house) dan benteng (fort), juga dapat mendekati bentuk wujud atau figure tersebut.

Tabel 2. Tabel konsep bentuk

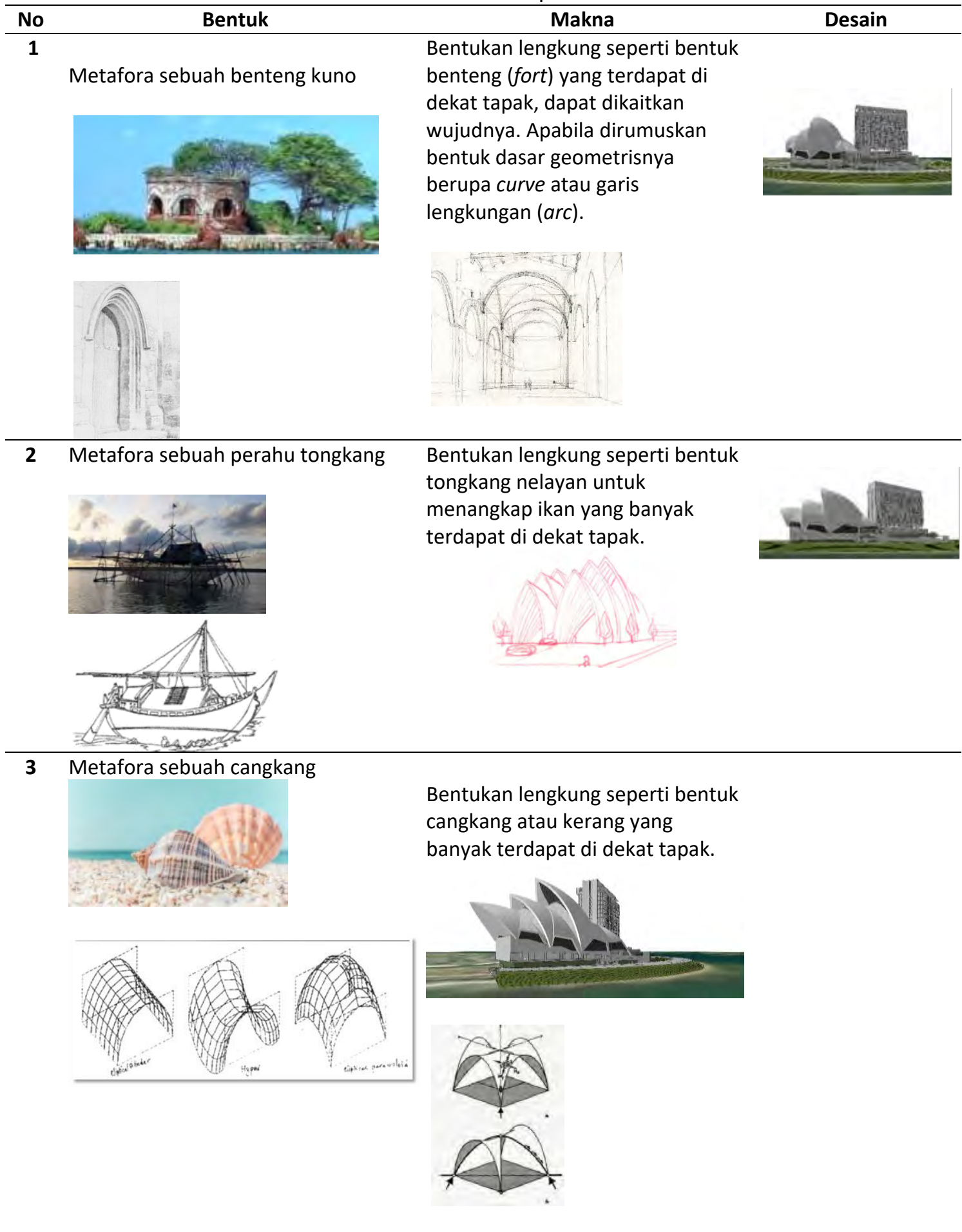

Sumber: Data dan analisis penulis, 2020 


\section{Zoning dan Program Ruang}

Pembagian zona berdasarkan pada sifat privasinya, berdasarkan kedekatan hubungan kegiatan, serta berdasarkan efektifitas utilitasnya. Misalnya daerah servis dan $\mathrm{BOH}$ sebaiknya berada dalam satu zona ruang, kemudian zona unit kamar berada dala satu kelompok juga.
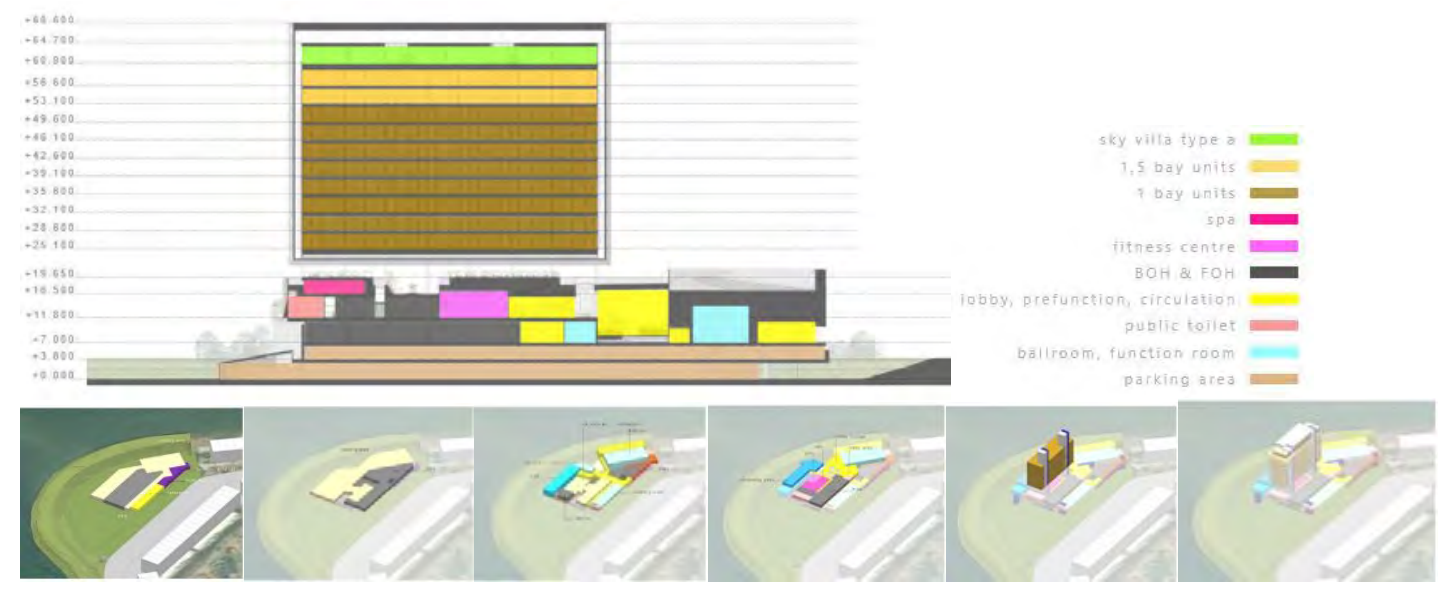

Gambar 22. Zoning

Sumber: Penulis, 2020

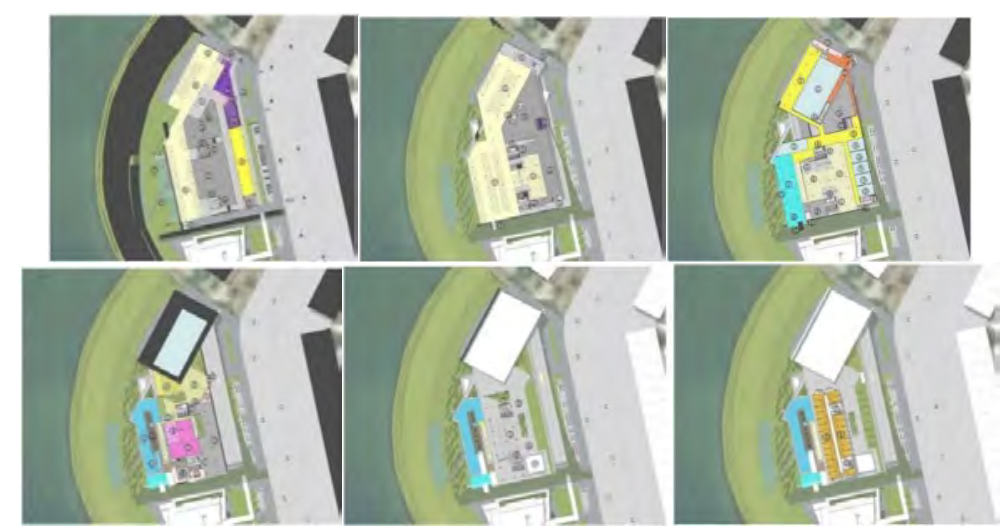

Gambar 23. Denah Lantai Bangunan Hotel

Sumber: Penulis, 2020

\section{Façade, Eksterior dan Interior}

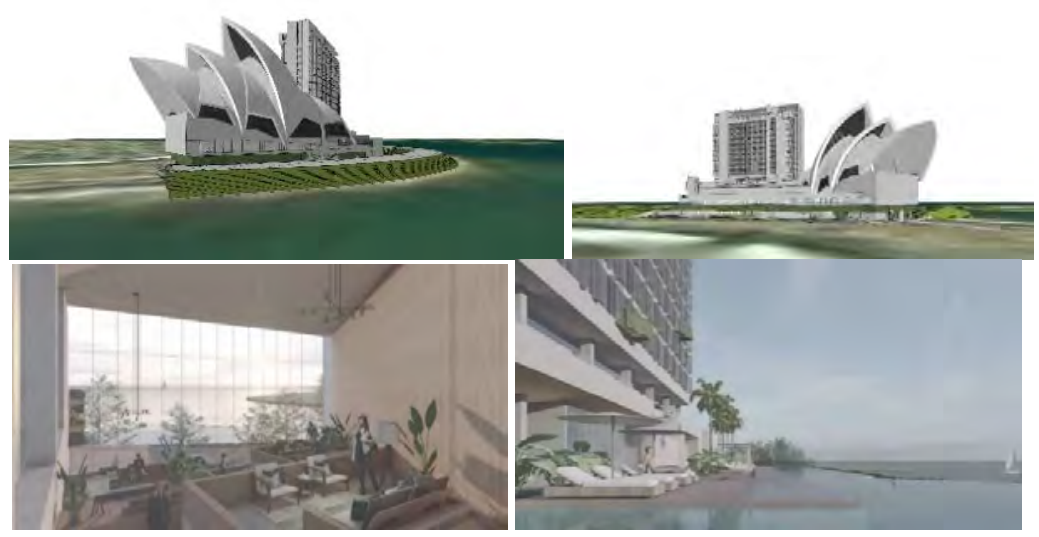

Gambar 24. Perspektif interior eksterior hotel resort

Sumber: Penulis, 2020 


\section{KESIMPULAN DAN SARAN}

\section{Kesimpulan}

Cara yang dilakukan dalam perancangan hotel resort di Pantai maju adalah dengan pendekatan kontekstual, yaitu dengan memperhatikan aspek alam (nature), sejarah setempat (history), dan aspek kegiatan manusia (activity) yang berlangsung di sekitar tapak.

Figure yang dapat merepresentasikan konteks perairan adalah bentuk cangkang dan perahu layar, sehingga figure tersebut dapat menjadi icon untuk konteks kawasan tepi air. Bentuk ballroom hotel resort yang dapat diakses publik maupun tamu hotel berwujud seperti cangkang atau layar perahu, sehingga sangat unik dan kontras dengan bentuk sekitarnya.

Karakter kegiatan sekitar tapak berupa kegiatan-kegiatan yang bersifat santai dan hiburan, baik itu berupa kegiatan komersial maupun yang non-komersial. Untuk itu perancangan hotel resort di pantai Maju memiliki ruang-ruang publik yang bersifat komersial maupun nonkomersial yang berhubungan dengan kegiatan di sekitarnya. Misalnya disediakan taman untuk pengunjung dan tamu hotel, restaurant dan café yang dapat diakses oleh pengunjung maupun tamu hotel.

\section{Saran}

Saran yang penulis berikan adalah bahwa perancangan arsitektur yang dilakukan oleh arsitek yang telah semakin dalam mempelajari arsitektur, perlu dilkakukan pemikiran yang dapat melebihi landasan pragmatis-nya, menuju suatu proses perancangan yang memasukkan idealisme pemikiran, sehingga semakin banyak karya arsitektur yang lebih bermakna.

\section{REFERENSI}

Antoniades, A. C. (1992). Poetics of Architecture: Theory of Design. New York: Van Nostrand Reinhold.

Bauer, M., Mösle, P., \& Schwarz, M. (2007). Green Building: Guidebook for Sustainable Architecture. Munich: Callwey Verlag.

Breen, A. \&. (1996). The New Waterfront: A Worldwide Success Story. Great Britain: T\&Hudson.

Broadbent, G. (1973). Design in Architecture. New York, Bisbane, Toronto, Chichester: John Wiley \& Sons.

Classe, O. (2000). Encyclopedia of Literary Translation in English (Vol. 2). London: Fitzroy Dearborn Publisher.

Dirjen Pariwisata, S. N. (1988). Pelaksanaan Ketentuan Usaha dan Penggolongan Hotel. Jakarta: Dirjen Pariwisata.

Echols, J. \&. (2003). Kamus Inggris Indonesia. Jakarta: PT Gramedia.

Hornby, A. (1974). Oxford Advanced Leaner's Dictionary of Current English. London: Oxford University Press.

Jormakka, K. (2008). Basics Design Methods. Berlin: Birkhauser Verlag AG.

K, T. A. (2016). Skripsi: Resort dengan Pendekatan Ekologi Arsitektur di Pantai Nampu Wonogiri. Surakarta: Universitas Sebelas Maret.

Kurniasih, S. (2009). Prinsip Hotel Resort: Studi Kasus Putri Duyung Cottage 51 Ancol Jakarta Utara. Jakarta: Universitas Budi Luhur.

Larson, M. L. (1998). Meaning Based Translation, A Guide to Cross-Language Equivalence. Boston: The University Press of America.

Lynch, K. A. (1960). The Image of the City. Amerika Serikat: The MIT Press.

Marlina, E. (2008). Panduan Perancangan Bangunan Komersial. Yogyakarta: Andy.

Ortony, A. (1979). Metaphor and Thought. Cambridge: Cambridge University Press.

Pendit, N. S. (1999). Ilmu Pariwisata: Sebuah Pengantar Perdana. Jakarta: PT. Pradnya Paramita. 
Richards, I. A. (1965). The Philosophy of Rhetoric. New York: Oxford University Press.

Schirmbeck, E. (1988). Gagasan Bentuk dan Arsitektur: Prinsip-Prinsip dalam Arsitektur Kontemporer. Bandung: Intermatra.

Snyder, C. J. (1979). Introduction to Architecture. New York: McGraw-Hill.

Sumarno, P. (1999). Skripsi: Hotel Resort Pantai di Jakarta. Depok: Universitas Indonesia.

Trisno, R., \& Lianto, F. (2019). Relationship Between Function-Form in the Expression of Architectural Creation. Advance: a SAGE Preprints Community, 1-6. 